\title{
THE RELATIONSHIP BETWEEN SOME SOLUBLE OSTEOGENIC MARKERS, ANGIOGENIC CYTOKINES/OTHER BIOLOGICAL PARAMETERS AND THE STAGES OF MULTIPLE MYELOMA EVALUATED ACCORDING TO THE DURIE-SALMON AND INTERNATIONAL PROGNOSTIC INDEX STRATIFICATION SYSTEMS
}

\author{
Vlastimil Scudla ${ }^{a *}$, Tomas Pika ${ }^{a}$, Marie Budikova ${ }^{b}$, Pavla Petrova ${ }^{b}$, Jaroslav Bacovskya, \\ Karel Srovnalik ${ }^{c}$, Jiri Minarik ${ }^{\mathrm{a}}$, Katerina Langova ${ }^{\mathrm{d}}$
}

\author{
a 3rd Department of Internal Medicine, University Hospital Olomouc, Palacky University Olomouc, Czech republic \\ ${ }^{b}$ Department of Clinical Biochemistry, University Hospital Olomouc \\ Department of Haematology, Hospital Vsetin \\ d Department of Medical Biophysics, Palacky University Olomouc \\ e-mail: vlastimil.scudla@fnol.cz
}

Received: July 30, 2009; Accepted: October 19, 2009

Key words: Multiple myeloma/Durie-Salmon staging system/International Prognostic Index/ $\beta_{2}$-microglobulin/ Thymidinekinase/sICTP/sHGF/sCD ${ }_{138}$ (syndecan-1)

Background: The aim of the present paper was to examine the correlation between serum concentrations of 12 soluble biological markers and stages of myeloma evaluated according to the Durie-Salmon (D-S) and International Prognostic Index (IPI) stratification systems.

Methods: We analyzed a non-pretreated group of 179 patients with MM stratified according to D-S and IPI. Serum levels of soluble biological markers were evaluated using ELISA, REA and quantitative sandwich enzymatic immunoassays. The data were analyzed using the Kruskal-Wallis and Mann-Whitney U tests.

Results: The staging system according to D-S revealed a highly significant relationship between all stages (I-III) in case of $\beta_{2}-\mathrm{m}(\mathrm{p}<0.0001)$ and sTK $(\mathrm{p}<0.001)$, in sICTP a significant difference was found only in stages II vs III $(\mathrm{p}<0.001)$ and I vs III $(\mathrm{p}<0.001)$, in case of $\mathrm{sCD}_{138}$ ( syndecan-1) in stages I vs II $(\mathrm{p}=0.006)$ and I vs III $(\mathrm{p}<0.001)$, in sVEGF only in stages I vs III $(p=0.006)$. In substages A vs B we found a significant difference in case of $\beta_{2}-\mathrm{m}$ $(p<0.0001), \operatorname{sTK}(p=0.041), \operatorname{sICTP}(p 0.0001), \operatorname{sOSP}(p=0.008), \operatorname{sHGF}(p<0.001), \operatorname{sCD} 138(p=0.001)$ and $s F a s(p=$ $0.001)$. The relationship between other factors and stages and substages according to D-S appeared nonsignificant. The IPI system showed a highly significant relationship between all 3 categories $(1-3)$ in case of $\beta_{2}-\mathrm{m}(\mathrm{p}<0.001)$, sTK $(p<0.0001)$ and sICTP $(p<0.0001)$, while in sHGF only in stages 2 vs $3(p<0.0001)$ and 1 vs $3(p<0.0001)$. In 4 parameters there were only discrete differences in 1 vs 3 : $\operatorname{sPINP}(\mathrm{p}=0.036), \operatorname{sOSP}(\mathrm{p}=0.002), \mathrm{sCD}_{138}(\mathrm{p}=0.03)$ and sFas $(p=0.012)$, in the remaining markers the analysis was negative.

Conclusions: A highly convincing relationship between myeloma stages and serum levels was found only in $\beta_{2}-\mathrm{m}$, sTK, sICTP and partly also in $\mathrm{sCD}_{138}$ (syndecan-1) and sHGF. More favourable was the IPI stratification system.

\section{INTRODUCTION}

Multiple myeloma (MM) is an unusually heterogeneous B-cell malignancy with an individually different clinical course, characterised by uncontrolled proliferation and progressive accumulation of plasma cells that selectively infiltrate the bone marrow (BM). This devastating cancer results from a high tumor burden with accompanying cytokine dysregulation, osteolytic bone disease and from deposition of high levels of immunoglobulin light chain ${ }^{1}$. The disease progression of MM is characterised by monoclonal plasma cell proliferation, dissemination and vascular circulation of plasma cells, and loss of programmed cell death leading to the accumulation of tumor cells ${ }^{2}$. The crucial role of the BM microenvironment and its ability to support the proliferation of tumour cells are currently being intensively investigated ${ }^{3}$. The adhesion of myeloma cells to BM stromal cells leads to the produc- tion of cytokines that support the growth of plasma cells and prevents them from apoptosis. The major plasma cell growth factors secreted are interleukin-6 (IL-6) and its soluble receptor (IL-6/sIL-6R) ${ }^{4}$. Neovascularisation and interactions between plasma cells and osteoclasts resulting in osteoclast activation are two important additional processes contributing to MM pathogenesis and its clinical manifestation. Vascular endothelial growth factor (VEGF) has several biological effects in MM pathogenesis. It modulates the activity of nuclear factor- $\mathrm{kB}$ (NF$\kappa \mathrm{B})$, increases the resorption activity of osteoclasts, and has an impact on proliferation, migration and survival of myeloma cells. Moreover, it may account for the increased microvessel density observed in the $\mathrm{BM}^{5-7}$. Hepatocyte growth factor (HGF) produced by myeloma cells is a pleiotropic cytokine which promotes tumor cell growth, bone marrow dissemination, inhibits osteoblast function and contributes to myeloma bone disease and BM angio- 
genesis ${ }^{8}$. Migration and invasion of myeloma cells require the secretion of metaloproteinase-2 (MMP-2) and MMP9 which are possibly modulated, in part, by syndecan-1 $\left(\mathrm{CD}_{138}\right)$, expressed in plasma cells and which can be shed from the surface of myeloma cells and circulate as soluble factor $^{9,10}$. The main regulator of osteoclast formation in $\mathrm{MM}$ is the receptor of nuclear factor $\kappa-\mathrm{B}$ ligand (RANKL) while osteoprotegerin (OPG) blocks this resorption process. Fas-L overexpression by myeloma cells reflects their high degree of malignancy while abnormal overexpression of apoptogenic receptors such as Fas-L defines the major malignant phenotype associated with progression of $\mathrm{MM}^{11,12}$.

As clinically oriented publications deal only sporadically with the relationship between soluble biological substances and clinically advanced MM stages, the purpose of our study was analysis of relationship between 12 soluble markers that characterise osteogenic, angiogenic and other biologically important substances and MM clinical stages (stage 1-3) evaluated according to the Durie-Salmon (D-S) $)^{13,14}$ and International Prognostic Index (IPI) ${ }^{15}$ and comparison of these two systems which are used in the pathobiology of this disease.

\section{PATIENTS AND METHODS}

The analyzed group of 179 multiple myeloma patients diagnosed according to the criteria of International Myeloma Working Group (IMWG) was examined before initiation of treatment from 2004-2008 $8^{14,16}$. The median age of the cohort study was 64 years (range 29-90), with $\mathrm{M} / \mathrm{F}$ ratio $1.2 ; 65.5 \%$ cases of $\mathrm{IgG}, 21 \% \mathrm{IgA}, 12 \%$ BenceJones (B-J) production only, $1 \%$ nonsecretory, $0.5 \%$ of $\mathrm{IgD}$, the serum monoclonal light chain was $\kappa$ in $63 \%$ and $\lambda$ in $36 \%$. Patients were staged according to D-S clinical staging system ${ }^{13}$ and IPI ${ }^{15}$.

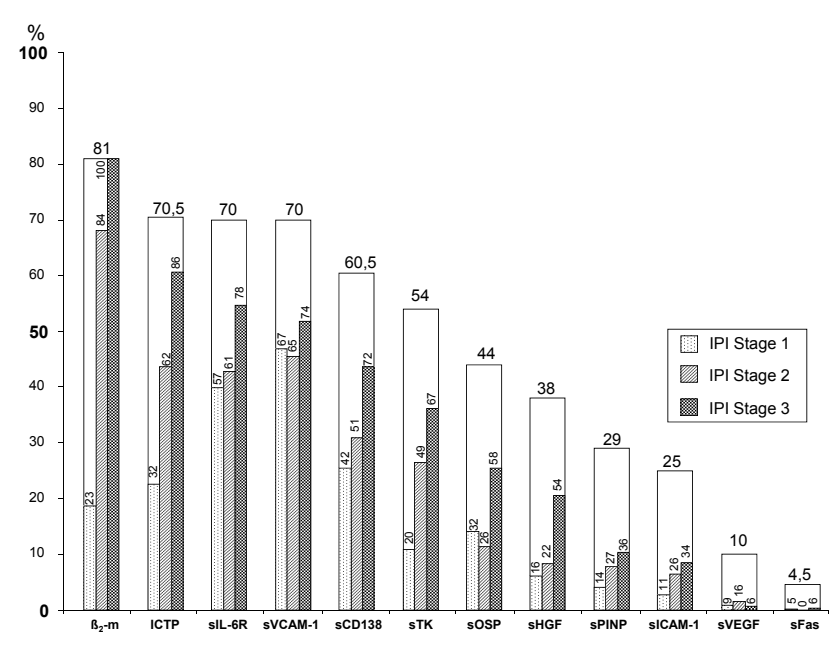

Fig. 1. Graphical representation of the occurrence of pathologic values of analysed markers and occurrence of varying values of multiple myeloma stages I-III provided according to International Prognostic Index stratification system.
The detection of $\beta_{2}-\mathrm{m}$ serum level was performed by Immulite 1000 (Siemens Medical Solutions Diagnostics, normal range 0.1-2.5 mg/1), thymidinekinase (sTK) serum level by a radioenzymoassay (REA kit, Immunotech Prague, normal range 0-10 U/1). The evaluation of sIL-6R (soluble interleukin-6 receptor, 10-90 ng/ml), sVCAM-1 (vascular cell adhesive molecule-1, 395-714 ng/ml), sICAM-1 (soluble intercellular cell adhesive molecule-1, 269-691 ng/ml) was performed by commercially available sandwich immunoassays (enzyme-linked immunosorbent assay, ELISA kit, Immunotech Prague), sICTP ( carboxy-terminal telopeptide of type-I, 0.3-6.0 $\mu \mathrm{g} / \mathrm{l}$, ELISA kit, Orion Diagnostica Espoo, Finland), sOPG (soluble osteoprotegerin 1.8- 6.4 pmol/1, ELISA kit Bio Vendor $\mathrm{GmbH}$ ), sPINP (N-terminal telopeptide of type-1 collagen, above 50 years 16.3-73.9 ug/1, modular Cobas 6000, Roche Diagnostics). Analysis of serum concentration of sHGF (hepatocyte grow factor, 671-1992 pg/ml), sVEGF (vascular endothelial growth factor, 62-707 pg/ $\mathrm{ml})$, syndecan- $1 / \mathrm{sCD}_{138}(37-123 \mathrm{ng} / \mathrm{ml})$ and sFas $(4792-$ $17150 \mathrm{pg} / \mathrm{ml}$ ) was performed with the help of quantitative sandwich enzymatic immunoassays (Quantikine RD kit, Minneapolis). Measurements were performed according to the manufacturer's instructions, in duplicate and were reproducible. The use of serum from patients for cytokine measurements was approved by the local ethics committee.

The patients' data were analyzed using the KruskalWallis or Mann-Whitney test, as appropriate, $\mathrm{p}$ - values < 0.05 were considered statistically significant.

\section{RESULTS}

The analysis showed that in the group of 179 patients with diagnosed MM before chemotherapy most frequent were elevated serum levels of $\beta_{2}-\mathrm{m}$, less frequent were sICTP, sIL6R, sVCAM-1, sSyndecan-1/CD ${ }_{138}$ a sTK, while pathological values of sOSP, sHGF, sPINP occurred in less than half of patients; only 10 and $4.5 \%$ of patients had pathological values of sVEGF and sFas (Fig. 1).

Stratification according to D-S revealed most frequently the stage III (56\%), while stage II and I in 28 and $17 \%$, substage B (patients with S-creatinine level > $170 \mu \mathrm{mol} / 1$ ) occurred only in $24 \%$ (Table 1 ). The occurrence of pathological values of evaluated parameters in the whole analyzed group divided into 3 clinical stages (stage I-III) and 2 substages (substage A-B) was as follows: $\beta_{2}$-m: stage I - $43 \%$, stage II - 78\%, stage III - 95\%, substage A - 75\%, substage B -100\%; sTK: I-13\%, II-48\%, III-69\%, A-51\%, and B-63\%; sIL-6R: I-65\%, II-56\%, III-78\%, A-66\% and B-79\%; sICAM-1: I-7\%, II-29\%, III-33\%, A-25\% and B-32\%; sVCAM-1: I-72\%, II-77\%, III-64\%, A-68\% and B-76\%; sICTP: I-33\%, II-67\%, III-82\%, A-60\% and B-97\%; sPINP: I-13\%, II-27\%, III-34\%, A-28\% and B-33\%; sOSP: I-32\%, II-31\%, III-53\%, A-37\% and B-65\%; sHGF: I-17\%, II-32\%, III-47\%, A-29\% and B-64\%; sVEGF: I-17\%, II-12\%, III-4\%, A-10\% and B-5\%; $\mathrm{sCD}_{138}$ (syndecan-1): I-26\%, II$60 \%$, III-71\%, A-52\% and B- $86 \%$; sFas: I- $0 \%$, II- $2 \%$, III- $6 \%$, A-3\% and B-8\%. A complex analysis of all 12 parameters 
The relationship between some soluble osteogenic markers, angiogenic cytokines/other biological parameters and the stages of multiple myeloma evaluated according to the Durie-Salmon and International Prognostic Index

stratification systems

Table 1. Serum levels of soluble osteogenic markers, angiogenic cytokines and biological parameters in stages I-III and substages A-B provided according to Durie-Salmon stratification system.

\begin{tabular}{|c|c|c|c|c|c|c|c|c|c|c|c|c|c|}
\hline \multirow{2}{*}{\multicolumn{2}{|c|}{$\frac{\text { Group }}{\text { MM (D-S) }}$}} & \multirow{3}{*}{$\begin{array}{c}\boldsymbol{\beta}_{2}-\mathbf{m} \\
30 \\
(17 \%)\end{array}$} & \multirow{3}{*}{$\begin{array}{c}\text { sTK } \\
30\end{array}$} & \multirow{3}{*}{$\begin{array}{c}\text { SIL-6R } \\
29\end{array}$} & \multirow{3}{*}{\begin{tabular}{|c|} 
sICAM-1 \\
27
\end{tabular}} & \multirow{3}{*}{\begin{tabular}{|c|} 
SVCAM-1 \\
29 \\
\end{tabular}} & \multirow{3}{*}{$\begin{array}{c}\text { sICTP } \\
30\end{array}$} & \multirow{3}{*}{$\begin{array}{c}\text { sPINP } \\
30\end{array}$} & \multirow{3}{*}{$\begin{array}{c}\text { sOSP } \\
28\end{array}$} & \multirow{3}{*}{$\begin{array}{c}\text { sHGF } \\
29\end{array}$} & \multirow{3}{*}{$\frac{\text { SVEGF }}{30}$} & \multirow{3}{*}{\begin{tabular}{|c|}
$\begin{array}{c}\text { syndecan-1 } \\
\left(\mathbf{s C D}_{138}\right)\end{array}$ \\
30
\end{tabular}} & \multirow{3}{*}{$\begin{array}{c}\text { sFas } \\
19\end{array}$} \\
\hline & & & & & & & & & & & & & \\
\hline \multirow[t]{2}{*}{ Stage I } & $\mathrm{n}$ & & & & & & & & & & & & \\
\hline & $\begin{array}{l}\text { median } \\
\text { (range) }\end{array}$ & $\begin{array}{c}2,20 \\
(1,0-8,2)\end{array}$ & $\begin{array}{c}5,7 \\
(1,3-18,8)\end{array}$ & $\begin{array}{l}100,0 \\
(52,9- \\
100,0)\end{array}$ & $\begin{array}{c}529,0 \\
(173-917)\end{array}$ & $\begin{array}{c}887,0 \\
(34-1625)\end{array}$ & $\begin{array}{c}4,6 \\
(1,8-53,0)\end{array}$ & $\begin{array}{c}49,1 \\
(22,0- \\
215,9)\end{array}$ & $\begin{array}{c}5,2 \\
(1,2-12,7)\end{array}$ & $\begin{array}{c}1159,0 \\
(498-8000)\end{array}$ & $\begin{array}{c}417,6 \\
(47,8- \\
1960,2) \\
\end{array}$ & $\begin{array}{c}64,3 \\
(2,5- \\
256,0) \\
\end{array}$ & $\begin{array}{l}6361,0 \\
(1179- \\
15539) \\
\end{array}$ \\
\hline \multirow[t]{2}{*}{ Stage II } & $\mathrm{n}$ & $\begin{array}{c}50 \\
(28 \%)\end{array}$ & 50 & 48 & 45 & 48 & 49 & 48 & 35 & 50 & 49 & 48 & 41 \\
\hline & $\begin{array}{l}\text { median } \\
\text { (range) }\end{array}$ & $\begin{array}{c}3,4 \\
(1,6-11,4)\end{array}$ & $\begin{array}{c}9,3 \\
(2,3-44,2)\end{array}$ & $\begin{array}{l}100,0 \\
(36,5- \\
100,0)\end{array}$ & $\begin{array}{c}575,0 \\
(252-1130)\end{array}$ & $\begin{array}{c}974,0 \\
(144-2164)\end{array}$ & $\begin{array}{c}6,8 \\
(2,8-69,7)\end{array}$ & $\begin{array}{c}53,5 \\
(11,4- \\
253,0)\end{array}$ & $\begin{array}{c}5,4 \\
(2,0-60,0)\end{array}$ & $\begin{array}{l}1594,3 \\
(550,0- \\
8000,0)\end{array}$ & $\begin{array}{c}277,6 \\
(5,0-1278,1)\end{array}$ & $\begin{array}{c}198,7 \\
(23,8 \\
256,0)\end{array}$ & $\begin{array}{c}7961,0 \\
(4605,0- \\
46655,0)\end{array}$ \\
\hline \multirow[t]{2}{*}{ Stage III } & $\mathrm{n}$ & $\begin{array}{c}99 \\
(55 \%) \\
\end{array}$ & 96 & 93 & 85 & 92 & 93 & 93 & 83 & 98 & 97 & 94 & 79 \\
\hline & $\begin{array}{l}\text { median } \\
\text { (range) }\end{array}$ & $\begin{array}{c}5,6 \\
(1,4-45,2)\end{array}$ & $\begin{array}{c}16,8 \\
(2,4-100,0)\end{array}$ & $\begin{array}{l}100,0 \\
(22,6- \\
100,0)\end{array}$ & $\begin{array}{c}559,0 \\
(100-1600)\end{array}$ & $\begin{array}{c}932,5 \\
(174-2500)\end{array}$ & $\begin{array}{c}12,8 \\
(3,1-616,0)\end{array}$ & $\begin{array}{c}59,0 \\
(12,0- \\
575,9)\end{array}$ & $\begin{array}{c}6,7 \\
(1,5-56,6)\end{array}$ & $\begin{array}{l}1772,0 \\
(492,0- \\
8000,0)\end{array}$ & $\begin{array}{c}193,7 \\
(34,5- \\
1990,0) \\
\end{array}$ & $\begin{array}{c}256,0 \\
(8,0- \\
256,0)\end{array}$ & $\begin{array}{l}7685,0 \\
(2653- \\
2000,0) \\
\end{array}$ \\
\hline \multirow[t]{2}{*}{ Substage A } & $\mathrm{n}$ & $\begin{array}{c}135 \\
(76 \%) \\
\end{array}$ & 133 & 127 & 117 & 127 & 130 & 129 & 109 & 133 & 134 & 129 & 104 \\
\hline & $\begin{array}{l}\text { median } \\
\text { (range) }\end{array}$ & $\begin{array}{c}3,5 \\
(1,1-19,4)\end{array}$ & $\begin{array}{c}10,9 \\
(1,3-100,0)\end{array}$ & $\begin{array}{l}100,0 \\
(22,6- \\
100,0)\end{array}$ & $\begin{array}{c}549,0 \\
(173,0- \\
1600,0) \\
\end{array}$ & $\begin{array}{c}883,0 \\
(34-2462,0)\end{array}$ & $\begin{array}{c}6,8 \\
(1,7-616,0)\end{array}$ & $\begin{array}{c}52,4 \\
(12,0- \\
575,9)\end{array}$ & $\begin{array}{c}5,6 \\
(1,2-60,0)\end{array}$ & $\begin{array}{l}1462,0 \\
(492,0- \\
8000,0)\end{array}$ & $\begin{array}{c}248,3 \\
(5,0- \\
1990,0) \\
\end{array}$ & $\begin{array}{c}150,4 \\
(2,5- \\
256,0)\end{array}$ & $\begin{array}{c}7326,0 \\
(1179,0- \\
46655,0)\end{array}$ \\
\hline \multirow[t]{2}{*}{ Substage B } & $\mathrm{n}$ & $\begin{array}{c}44 \\
(24 \%)\end{array}$ & 43 & 43 & 40 & 42 & 42 & 42 & 37 & 44 & 42 & 43 & 35 \\
\hline & $\begin{array}{l}\text { median } \\
\text { (range) }\end{array}$ & $\begin{array}{c}10,3 \\
(2,7-45,2)\end{array}$ & $\begin{array}{c}15,4 \\
(2,4-100,0)\end{array}$ & $\begin{array}{l}100,0 \\
(36,5- \\
100,0)\end{array}$ & $\begin{array}{c}578,5 \\
(100,0- \\
1600,0) \\
\end{array}$ & $\begin{array}{c}991,0 \\
(330,0- \\
2500,0-\end{array}$ & $\begin{array}{c}19,1 \\
(4,8-101,3)\end{array}$ & $\begin{array}{c}59,0 \\
(11,4-219,6)\end{array}$ & $\begin{array}{c}7,8 \\
(2,2-56,6)\end{array}$ & $\begin{array}{l}2421,0 \\
(686,0- \\
8000,0) \\
\end{array}$ & $\begin{array}{c}204,6 \\
(50,0- \\
1205,0) \\
\end{array}$ & $\begin{array}{l}256,0 \\
(27,5- \\
256,0)\end{array}$ & $\begin{array}{c}10146,0 \\
(3385,0- \\
20000,0)\end{array}$ \\
\hline $\begin{array}{c}\text { Statistical } \\
\text { significance }\end{array}$ & $\begin{array}{c}\text { Comparison } \\
\text { of all stages } \\
\text { (I-III) }\end{array}$ & $<0,0001$ & $<0,0001$ & NS & NS & NS & $<0,0001$ & NS & 0,022 & 0,001 & 0,004 & $<0,0001$ & NS \\
\hline
\end{tabular}

Table 2. Serum levels of soluble osteogenic markers, angiogenic cytokines and biological parameters in stages 1-3 provided according to International Prognostic Index stratification system.

\begin{tabular}{|c|c|c|c|c|c|c|c|c|c|c|c|c|c|}
\hline \multicolumn{2}{|c|}{$\begin{array}{c}\text { Group } \\
\text { MM (IPI) }\end{array}$} & \multirow{2}{*}{$\begin{array}{c}\boldsymbol{\beta}_{2}-\mathbf{m} \\
31(17 \%)\end{array}$} & \multirow{2}{*}{$\begin{array}{r}\text { sTK } \\
31\end{array}$} & \multirow{2}{*}{$\begin{array}{c}\text { sIL-6R } \\
30\end{array}$} & \multirow{2}{*}{$\begin{array}{c}\text { SICAM-1 } \\
28\end{array}$} & \multirow{2}{*}{\begin{tabular}{|c} 
SVCAM-1 \\
30
\end{tabular}} & \multirow{2}{*}{$\begin{array}{c}\text { sICTP } \\
31\end{array}$} & \multirow{2}{*}{$\begin{array}{c}\text { sPINP } \\
31\end{array}$} & \multirow{2}{*}{$\begin{array}{c}\text { sOSP } \\
28\end{array}$} & \multirow{2}{*}{$\begin{array}{c}\text { sHGF } \\
31\end{array}$} & \multirow{2}{*}{$\begin{array}{c}\text { SVEGF } \\
31\end{array}$} & \multirow{2}{*}{$\begin{array}{c}\begin{array}{c}\text { syndecan-1 } \\
\left(\mathrm{sCD}_{138}\right)\end{array} \\
31\end{array}$} & \multirow{2}{*}{$\begin{array}{r}\text { sFas } \\
21\end{array}$} \\
\hline Stage 1 & $\mathrm{n}$ & & & & & & & & & & & & \\
\hline & $\begin{array}{l}\text { median } \\
\text { (range) }\end{array}$ & $\begin{array}{c}1,9 \\
(1,1-3,3)\end{array}$ & $\begin{array}{c}6,5 \\
(1,3-19,3)\end{array}$ & $\begin{array}{c}95,6 \\
(52,9- \\
100,0)\end{array}$ & $\begin{array}{c}500,5 \\
(173,0- \\
995,0)\end{array}$ & $\begin{array}{r}804,0 \\
(174,0- \\
2164,0)\end{array}$ & $\begin{array}{c}4,1 \\
(1,7-14,2)\end{array}$ & $\begin{array}{c}49,9 \\
(22,0- \\
133,3)\end{array}$ & $\begin{array}{c}3,7 \\
(1,2-60,0)\end{array}$ & $\begin{array}{c}1169,0 \\
(498- \\
8000,0)\end{array}$ & $\begin{array}{c}340,8 \\
(5,0-923,8)\end{array}$ & $\begin{array}{c}95,1 \\
(2,5- \\
256,0)\end{array}$ & $\begin{array}{l}6013,0 \\
(4048- \\
46655)\end{array}$ \\
\hline \multirow[t]{2}{*}{ Stage 2} & $\mathrm{n}$ & $51(28 \%)$ & 49 & 46 & 42 & 46 & 48 & 48 & 41 & 49 & 50 & 49 & 38 \\
\hline & $\begin{array}{l}\text { median } \\
\text { (range) }\end{array}$ & $\begin{array}{c}3,1 \\
(1,8-5,3)\end{array}$ & $\begin{array}{c}11,2 \\
(2,3-100,0)\end{array}$ & $\begin{array}{l}100,0 \\
(22,6- \\
100,0)\end{array}$ & $\begin{array}{c}592,0 \\
(252,0- \\
921,0)\end{array}$ & $\begin{array}{c}867,0 \\
(144,0- \\
2003,0)\end{array}$ & $\begin{array}{c}7,1 \\
(2,9-31,6)\end{array}$ & $\begin{array}{c}49,5 \\
(16,0-575,9)\end{array}$ & $\begin{array}{c}5,7 \\
(1,5-15,6)\end{array}$ & $\begin{array}{c}1383,0 \\
(492,0- \\
8000,0)\end{array}$ & $\begin{array}{c}244,8 \\
(34,5- \\
1990,0)\end{array}$ & $\begin{array}{l}134,0 \\
(10,9- \\
256,0)\end{array}$ & $\begin{array}{l}7576,0 \\
(1179- \\
13217)\end{array}$ \\
\hline \multirow[t]{2}{*}{ Stage 3} & $\mathrm{n}$ & 97 (54\%) & 95 & 93 & 86 & 92 & 92 & 91 & 76 & 96 & 94 & 91 & 79 \\
\hline & $\begin{array}{l}\text { median } \\
\text { (range) }\end{array}$ & $\begin{array}{c}6,7 \\
(3,0-45,2)\end{array}$ & $\begin{array}{c}16,5 \\
(2,4-100,0)\end{array}$ & $\begin{array}{l}100,0 \\
(36,5- \\
100,0)\end{array}$ & $\begin{array}{c}573,5 \\
(100,0- \\
1600,0)\end{array}$ & $\begin{array}{c}1002,5 \\
(34,0- \\
2500,0)\end{array}$ & $\begin{array}{c}13,0 \\
(3,1-616,0)\end{array}$ & $\begin{array}{c}63,0 \\
(11,4-348,9)\end{array}$ & $\begin{array}{c}7,1 \\
(2,2-56,6)\end{array}$ & $\begin{array}{l}2199,5 \\
(535,0- \\
8000,0)\end{array}$ & $\begin{array}{c}203,7 \\
(46,8- \\
1679,3)\end{array}$ & $\begin{array}{c}256,0 \\
(8,0- \\
256,0)\end{array}$ & $\begin{array}{c}8381,0 \\
(2653,0- \\
20000,0)\end{array}$ \\
\hline $\begin{array}{c}\text { Statistical } \\
\text { significance }\end{array}$ & $\mid \begin{array}{c}\text { Comparison } \\
\text { of all stages } \\
1-3\end{array}$ & $<0,0001$ & $<0,0001$ & 0,016 & NS & 0,041 & $<0,0001$ & 0,017 & 0,001 & $<0,0001$ & NS & 0,001 & 0,003 \\
\hline
\end{tabular}

for all 3 stages of MM (I-III) revealed highly significant differences $(\mathrm{p}<0.0001)$ for $\beta_{2}-\mathrm{m}$, sTK, sICTP, and syndecan-1, less important differences in the case of sOSP, sHGF and sVEGF while for the remaining 5 parameters the levels were not statistically significant (Table 1). Separate analysis of the differences among all clinical stages (I-III) revealed statistically significant differences only in $\beta_{2}-\mathrm{m}$ and sTK and between stages II vs. III and I vs. III only in sICTP and I vs II and I vs III in $\mathrm{sCD}_{138}$ (syndecan-1). In 2 other markers, i.e. in sHGF and sVEGF statistically significant differences were found only in patients with initial, asymptomatic MM phase (stage I) and most advanced phase of disease (stage III). No statistically significant difference was found between stages I-III in case of sIL-6R, sICAM-1, sVCAM-1, sPINP, sOSP and sFas. There were statistically significant differences between patients with present and absent disorders of renal function, i.e. between substage $\mathrm{A}$ and $\mathrm{B}$, only in case of $\beta_{2}-\mathrm{m}$, sTK, sICTP, sOSP, sHGF, sSyndecan and sFas, while sIL-6R, sICAM-1, sVCAM-1, sPINP and sVEGF was negative (Table 3 ). 
Table 3. Results of statistical analysis of serum levels of soluble osteogenic markers, angiogenic cytokines and biological parameters in multiple myeloma stages provided according to Durie-Salmon and International Prognostic Index stratification system.

\begin{tabular}{|c|c|c|c|c|c|c|c|c|c|c|c|c|c|}
\hline MM & & $\boldsymbol{\beta}_{2}-\mathbf{m}$ & sTK & sIL-6R & sICAM-1 & sVCAM-1 & sICTP & sPINP & sOSP & sHGF & sVEGF & $\begin{array}{c}\text { syndecan-1 } \\
\left(\mathrm{sCD}_{138}\right)\end{array}$ & sFas \\
\hline \multirow{3}{*}{ D-S } & $\begin{array}{c}\text { Stage I } \\
\text { II } \\
\text { II }\end{array}$ & 0,035 & $<0,0001$ & NS & NS & NS & NS & NS & NS & NS & NS & 0,006 & NS \\
\hline & III & & & NS & NS & NS & $<0,0001$ & NS & NS & NS & NS & NS & NS \\
\hline & III & $<0,0001$ & $<0,0001$ & NS & NS & NS & $<0,0001$ & NS & NS & 0,0012 & 0,006 & $<0,0001$ & NS \\
\hline & $\begin{array}{r}\text { Substage A } \\
\text { B }\end{array}$ & $<0,0001$ & 0,041 & NS & NS & NS & $<0,0001$ & NS & 0,008 & $<0,0001$ & NS & 0,001 & 0,001 \\
\hline \multirow{3}{*}{ IPI } & $\begin{array}{l}2 \\
2\end{array}$ & $<0,0001$ & 0,012 & NS & NS & NS & 0,006 & NS & NS & NS & NS & NS & NS \\
\hline & 3 & $<0,0001$ & $<0,012$ & NS & NS & NS & 0,0001 & NS & NS & 0,0001 & NS & NS & NS \\
\hline & 3 & $<0,0001$ & $<0,0001$ & NS & NS & NS & $<0,0001$ & 0,036 & 0,002 & $<0,0001$ & NS & 0,03 & 0,012 \\
\hline
\end{tabular}

The IPI stratification system revealed the most frequent presence of category $3(55 \%)$, less frequent was category $2(28 \%)$ and the least frequent was category 1 (17\%). The occurrence of pathological values of analyzed parameters in the group divided into 3 prognostic categories according to IPI is given in Fig. 1. A complex comparison of all 12 analyzed markers in all 3 prognostic MM categories (1-3) showed highly significant differences $(\mathrm{p}<$ $0.0001)$ for $\beta_{2}-\mathrm{m}$, sTK and sICTP, less significant differences for sIL-6R, sVCAM-1, sPINP, sOSP, syndecan-1 and sFas, while in the remaining 2 parameters, sICAM- 1 and sVEGF, serum levels did not differ statistically significantly (Table 2). Statistically significant differences between all categories (1-3) were found only for $\beta_{2}-\mathrm{m}$, sTK and sICTP, between stages 2 vs 3 and 1 vs 3 in case of sHGF. In other 4 markers, sPINP, sOSP, syndecan- 1 and sFas, significant differences were found only between category 1 (with most favourable prognosis) and category 3 (patients with worse prognosis). No statistically significant relationship between serum concentration and clinical stage of the disease was found with sIL-6R, sICAM-1, sVCAM-1 and sVEGF (Table 3).

\section{DISCUSSION}

The analysis confirmed that many of the evaluated biological markers connected to the pathobiology of $\mathrm{MM}$ are at the time of diagnosis related to the volume of the tumour mass, i.e. to MM progression. Therefore it is not surprising that all evaluations confirmed a close relationship between the key prognostic marker, which is the basic criterion of all recent stratification systems in $\mathrm{MM}$, namely $\beta_{2}-\mathrm{m}$ and individual stages of the disease and state of renal function ${ }^{15,17}$. Increase in $\beta_{2}-\mathrm{m}$ in $\mathrm{MM}$ is due not only to enhanced synthesis and turnover at the level of cell membranes but also to intensified cell death. Its level is related to disease progression and the state of renal function and moreover to disease activity and internal biological processes in myeloma tissue and activation grade of $\mathrm{T}$ and $\mathrm{B}$ cell systems. Highly favourable was also the evaluation of the relationship between sTK level which is the marker with important prognostic potential to individual stages of the disease ${ }^{18}$. This finding is not surprising given that the level of sTK expresses a complex proliferation capacity and mass of myeloma cells. Therefore, it is part of one prognostic stratification system $^{17,18}$. Evaluation of the circulating form of sIL-6R was made with respect to the key position of the IL-6/IL6R complex in interaction with the signal gp130 molecule, its role in activation of mitogen-activated protein kinase (MAPK) and activation of phosphatidylinositol 3-kinase (PI3K/Akt) pathway, which is closely related to proliferation and apoptosis of myeloma cells. We have already demonstrated the relationship between sIL-6R and MM activity, stage and prognosis ${ }^{19,20}$. The presented evaluation did not prove, except a complex evaluation of the group according to IPI, any relationship between sIL-6R level and individual MM stages. This supports conclusions of our previous analysis, which did not reveal prognostic importance of sIL-6R levels in the serum of peripheral blood and bone marrow ${ }^{17}$. The rationale for evaluating the relationship with sVCAM-1 and sICAM-1 was based on the known role of both cytoadhesive molecules in the process of bone marrow invasion by myeloma cells, their effect on proliferation and survival of myeloma cells in the microenvironment of bone marrow, and in the process of their extramedular dissemination ${ }^{21}$. Despite the previously 
demonstrated relationship between both molecules and some key markers of MM (e.g.. sVCAM-1 vs sIL-2R, sIL$6 \mathrm{R}$ and $s \mathrm{TNF}-\alpha$ ), their relationship to myeloma progression was not proved in the present study ${ }^{22}$.

Highly important was the finding of a significant relationship between all MM stages (I-III) and substage B (according to D-S) and serum concentration of SICTP, one key and highly sensitive parameter of bone metabolism in MM. It is known that sICTP levels are closely related to the grade of osteoclastic bone degradation ${ }^{23}$, but sICTP serum level increases also at renal insufficiency ${ }^{24}$. A close relationship between sICTP and MM progression and especially MM prognosis is certainly associated with this circumstance ${ }^{23}$. Even previous studies have shown that sICTP levels are related to the intensity of bone pain, number and severity of osteolytic lesions and bone fractures, i.e. the signs of progression of myeloma bone disease $^{23,25}$. This study as well as another study dealing with the same issue showed a very close relationship between sICTP levels and stages 1-3 and substage B of DurieSalmon staging ${ }^{25}$. Our results moreover revealed a very close relationship with prognostic criteria (1-3) within IPI stratification. It appears that sICTP as an easy methodological and economical marker provides clear information about the presence of a very early skeletal myeloma lesion, which can be detected only by means of MRI but not by conventional radiography of the skeleton ${ }^{26}$. ICTP may be also used not only for evaluation of MM progression and activity, but also for the prediction of skeletal damage, and bone disease progression in $\mathrm{MM}^{27}$. In accordance with sporadic previous studies, evaluation of serum levels of sPINP correlated with the grade of osteoblastic activity and bone neoplasms ${ }^{23,25}$. Serum levels of PINP in individual stages of the disease (I-III according D-S) did not differ, the only significant difference being between stage 1 and 3 according to IPI, which can be explained by paradoxical increase due to reparatory activation of osteoblasts caused by microfractures. Neither relationship between serum concentrations of sPINP and expressed disorder of renal function was proved ${ }^{23,25}$. OSP, acting as a decoy receptor antagonist for receptor activator of nuclear factor $\kappa-\mathrm{B}$ ligand (RANKL) is produced by osteoblasts and stromal cells. Our previous study revealed that the progression of MM and myeloma bone disease depends on the balance between RANKL and OPG, which is of major importance in bone homeostasis. Involvement of the skeleton is associated with enhanced production of RANKL in the microenvironment of bone marrow and decreased secretion of OPG leading to decreased activity and reduced quantity of osteoblasts. Earlier analyses have shown that in MM the serum activity of sOPG is lower than in healthy persons ${ }^{28}$. In contrast to the previous study ${ }^{29}$, but in harmony with another similar study ${ }^{30}$, our analysis showed that MM progression is not associated with decreased serum levels of sOSP, exceptional was only the difference between stage 1 vs 3 according to IPI. In harmony with previous experience, significant relationship between $\mathrm{sOPG}$ level and disorder of renal function, i.e. the presence of substage B according to D-S was confirmed ${ }^{29}$. It is evident that isolated evaluation of
sOPG serum levels without simultaneous determination of RANKL level is ineffective. Potentially valuable for clinical practice is, according to actual data, the evaluation of RANKL/OPG index, much more suitable for determination of the state of RANKL/OPG or other functionally related merkers, e.g. DKK-1 protein, macrophage inflammatory protein-1 (MIP-1 $\alpha$ ), MIP-1 $\beta$, IL-3, IL-1 $\beta$, stromal derived factor-1 (SDF-1 $\alpha$ ), frizzled-related protein-2 (sFRP-2) ${ }^{31}$. In harmony with studies reporting on elevated sHGF in MM in 30-50\%, we found elevation of sHGF, this pleiotropic multifunctional cytokine playing a crucial role in MM biology (activation of osteoclastic resorption, inhibition of osteoblastic neoplasm, stimulation of neoangiogenesis and proliferation as well as mobilization of myeloma plasmocytes) in $38 \%$ (ref. $^{10,31,32}$ ). Similarly to Sugimura ${ }^{33}$, we observed significantly higher values of sHGF in patients with elevated creatinine, in our study in substage B according to D-S. The proved negative relationship between elevated serum levels of sHGF and prognosis ${ }^{10}$ is explained also by a repeatedly proved significant dependence on MM progression because significant relationship of sHGF levels measured by us was proved, similarly to previous study, using both stratification systems (D-S and IPI) when comparing the initial MM stage (stage I) and the most advanced stage (stage III) and in case of IPI also when comparing stage 2 vs 3 (ref. ${ }^{34}$ ). This finding supports the preceding fact that sHGF level has an inverse relation to the level of serum albumin, a crucial criterion of IPI together with $\beta_{2}-\mathrm{m}^{34}$. The importance of HGF role in MM pathobiology is supported by the finding of its high levels in active, progressive form of the disease $^{32}$ and decreased levels in favourable therapeutical response ${ }^{10}$.

Recent studies indicate that sVEGF, this highly potential angiogenic peptide is involved not only in acceleration of angiogenesis, but also in MM progression, progression of myeloma bone disease and therapeutical resistance ${ }^{5}$, after successful chemotherapy its level decreases ${ }^{35,36}$. Our analysis showed a suprising tendency to decrease of sVEGF serum levels with advanced stages of the disease, i.e. I-III and in substage B compared to A (according to D-S) and advanced prognostic index 1-3 (according to IPI). However, the found differences were statistically insignificant except a complex evaluation and difference I vs III (according to D-S). Although the missing significance of differences is in harmony with the study of Sezer ${ }^{36}$, but discrepant from studies proving relationship between sVEGF levels and activity and progression grade of MM (difference between stage III vs I+II) ) $^{34,35}$. The above facts indicate that the follow-up of sVEGF serum levels is of limited importance for evaluation of myeloma mass volume in the organism. It is known that syndecan-1 $\left(\mathrm{sCD}_{138}\right)$ a heparan sulphate proteoglycan, expressed on and actively shed from the surface of most myeloma cells. Syndecan- $1\left(\mathrm{sCD}_{138}\right)$, multifunctional regulator of myeloma pathobiology mediates cell-cell adhesion, induces apoptosis and inhibits growth of myeloma tumor cells and also modulates myeloma bone disease by inhibiting osteoclast formation and promoting osteoblast differentiation, it may also mobilize cytokines a.g. $\mathrm{HGF}^{37}$. 
Syndecan-1 is also present in the myeloma microenvironment and acts to promote aggressive myeloma behaviour. Previous studies have demonstrated elevated levels of syndecan- 1 in the serum of patients with MM and proved its negative prognostic importance and strong correlation between increased level of serum $\mathrm{sCD}_{138}$ and tumour mass, as assessed by percent of bone marrow plasmacytosis (BMPC), $\beta_{2}-\mathrm{m}$ and $\mathrm{MM}$ activity ${ }^{38,39}$. High levels of $\mathrm{sCD}_{138}$ correlate with tumour mass and have a significant impact on the biology of MM by virtue of its pleiotrophic effects on the cell behaviour ${ }^{38}$. The occurrence of enhanced serum levels of syndecan-1 in MM varies from 35\% (ref. ${ }^{38}$ ) to $79 \%$ in the literature ${ }^{9}$, in our group elevated values were found in $61 \%$ of patients. Although our complex analysis revealed statistically significant relationship to tumour mass volume, a detailed analysis showed statistically significant differences especially when comparing stage 1 vs 2 and 1 vs 3 , also in substages A vs B. This finding support previous studies reporting statistically significant relationship between levels of syndecan- 1 and values of $\beta_{2}$ m, BMPC (\%), serum of M-protein level ${ }^{38,40}$, or B-J urie/24 $\mathrm{hrs}$, and levels of sIL6R, sICTP, and stage of MM progression evaluated according to D-S $\mathrm{S}^{9,10,19}$. However, our conclusions are discrepant from studies that did not record relationship between serum levels of syndecan-1 and the volume of tumour mass ${ }^{41,42}$. Surprising was our finding of only statistically limit difference of serum levels of syndecan-1 during complex evaluation of all three prognostic categories according to IPI and at tagetted comparison of index 1 vs 3 . This finding appears exceptional with respect to previous numerous studies proved a significant relationship between serum levels of syndecan-1 and levels of $\beta_{2}-\mathrm{m}^{9,38,39,40}$ and $\mathrm{MM}$ prognosis $\mathrm{MM}^{9,39,42,43}$. Thus, serum levels of syndecan-1 do not clearly reflect tumour load and renal failure, nor many other biological aspects of the disease $^{9,10}$. Our study indicates that evaluation of serum levels of $\mathrm{sCD}_{138}$ is not a reliable marker for assessment of tumour mass volume especially due to the actually prevailing stratification system according to IPI. The both overexpression and secretion of Fas-L by a number of myeloma cell clones reflect a high degree of malignancy ${ }^{44}$. By measuring Fas-L in plasma cells showed that this receptor occured at high levels in severely anemic MM patients and in some patients with stage III $\mathrm{MM}^{11}$. Soluble Fas level in the serum was increased in patients with agressive non-Hodgkins lymphoma and was independent prognostic factor $^{45}$. But analysis of serum levels in our group showed that elevated levels of sFas were present only in $4.5 \%$ of patients and concentrations in stages I-III (according to D-S) were highly similar. Statistically significant difference was evident only when comparing substages A vs. $\mathrm{B}$, which indicates depedence of serum levels on the state of renal function. Stratification of patients according to IPI showed different values only between prognostic category 1 and 3 . It is concluded that analysis of serum levels of $\mathrm{sFas}$ is of no practical importance in MM.

\section{CONCLUSIONS}

The present study concludes that of a large scale of examined angiogenic cytokines, osteogenic markers and other biological parameters, good, statistically significant and useful for clinical practice were only serum levels of $\beta_{2}-\mathrm{m}$, sTK, sICTP and partly syndecan- $1\left(\mathrm{sCD}_{138}\right)$ and sHGF. The found relationships contribute to better knowledge of pathobiology of multiple myeloma. This study is to be completed by future, more extensive analysis of their mutual relationship, difference from MGUS and assessment of their prognostic potential.

\section{LIST OF ABBREVIATIONS}

\begin{tabular}{|c|c|}
\hline BMPC & Bone marrow plasma cell \\
\hline$\beta_{2}-\mathrm{m}$ & $\beta-{ }_{2}$ microglobulin \\
\hline BM & Bone marrow \\
\hline D-S & Durie-Salmon \\
\hline ELISA & Enzyme-linked immunosorbent assay \\
\hline $\mathrm{HGF}$ & Hepatocyte growth factor \\
\hline ICTP & Carboxy-terminal telopeptide of type-I \\
\hline IPI & International Prognostic Index \\
\hline IL-6R & Interleukin-6 receptor \\
\hline ICAM-1 & Intercellular cell adhesive molecule- 1 \\
\hline IL-6 & Interleukin-6 \\
\hline IMWG & International Myeloma Working Group \\
\hline $\operatorname{IgG}$ & Immunoglobuline type $G$ \\
\hline MRI & Magnetic resonance imaging \\
\hline MAPK & Mitogen-activated protein kinase \\
\hline $\mathrm{M} / \mathrm{F}$ & Male/female ratio \\
\hline MMP-2 & Metalloproteinase-2 \\
\hline MM & Multiple myeloma \\
\hline $\mathrm{NF}-\kappa \mathrm{B}$ & Nuclear factor-кB \\
\hline OSP & Osteoprotegerin \\
\hline PI3K & Phosphatidylinositol 3-kinase \\
\hline PINP & N-terminal telopeptide of type- 1 collagen \\
\hline REA & Radioenzymoassay \\
\hline RANKL & Receptor of nuclear factor $\kappa-B$ ligand \\
\hline TNF- $\alpha$ & Tumor necrosis factor- $\alpha$ \\
\hline TK & Thymidinekinase \\
\hline VEGF & Vascular endothelial growth factor \\
\hline VCAM-1 & Vascular cell adhesive molecule-1 \\
\hline
\end{tabular}

\section{ACKNOWLEDGEMENTS}

This study was supported by grant IGA MHCR NR 9500-3 and NR 9489-3.

\section{REFERENCES}

1. Sanderson RD, Yang Y. Syndecan-1: a dynamic regulator of the myeloma microenvironment. Clin Exp Metastasis 2008; 25: 149-159.

2. Greipp PR. Prognosis in myeloma. Mayo Clin Proc 1994; 69: 895-2000.

3. Yacoby S, Pearse RN, Johnson CL, Barlogie B, Choi Y, Epstein J. Myeloma interacts with the bone marrow microenvironmentes 
induce osteoclastogenesis and is dependent on osteoclast activity. Br J Haematol 2002; 116: 278-290.

4. Chauhan D, Uchiyama H, Akbarali Y, Urashima M, Yamamoto K, Libermann TA, et al. Multiple myeloma cell adhesion - induced interleukin-6 expression in bone marrow stromal cells involves activation of NF-к B. Blood 1996; 87: 1104-1112.

5. Podar K, Anderson KC. Inhibition of VEGF signaling pathways in multiple myeloma and other malignancies. Cell Cycle 2007; 6: 538-542.

6. Vacca A, Ria R, Ribatti D, Semeraro F, Djonov V, Di Raimondo $\mathrm{F}$, et al. A paracrine loop in the vascular endothelial growth factor pathway triggers tumor angiogenesis and growth in multiple myeloma. Haematologica 2003; 88: 176-185.

7. Bellamy WT. Expression of vascular endothelial growth factor and its receptor in multiple myeloma and other hematopoietic malignancies. Sem Oncol 2001; 28: 551-559.

8. Holt RV, Fagerli VM, Baykov V, Rø TB, Hov H, Waage A, et al. Hepatocyte growth factor promotes migration of human myeloma cells. Haematologica 2008; 93: 619-622.

9. Seidel C, Sandan A, Hjorth M, Turesson I, Dahl IMS, Abildgaard $\mathrm{N}$, et al. Serum syndecan-1: a new independent prognostic marker in multiple myeloma. Blood 2000; 95: 388-392.

10. Seidel C, Børset M, Øyvind H, Cao D, Abildgaard N, HjorthHansen $\mathrm{H}$, et al. High levels of soluble syndecan-1 in myelomaderived bone marrow: modulation of hepatocyte growth factor activity. Blood 2000; 96: 3139-3146.

11. Silvestris F, Tucci M, Cafforio P, Dammacco F. Fas-L-upregulatio by highly malignant myeloma plasma cells: role in the pathogenesis of anemia and disease progression. Blood 2001; 97: 1155-1164.

12. Hata H, Matsuzaki H, Takeya M, Takatsuki K. Fas/Apo-1 $\left(\mathrm{CD}_{95}\right)$ - mediated and $\mathrm{CD}_{95}$-independent apoptosis of malignant plasma cells. Leuk Lymphoma 1996; 24: 35-42.

13. Durie BGM, Salmon SE. A clinical staging system for multiple myeloma. Cancer 1975; 36: 842-854.

14. Adam Z, Česká myelomová skupina a Myelomová sekce ČHS pro diagnostiku a léčbu mnohočetného myelomu: Diagnostika a léčba mnohočetného myelomu. Transf Hematol dnes 2005; 11(Suppl 1): $3-51$.

15. Greipp PR, San Miguel J, Durie BGM, et al. International Staging System for multiple myeloma. J Clin Oncol 2005; 23: 3412-3420.

16. International Myeloma Working Group. Criteria for the clasification of monoclonal gammopathies, multiple myeloma and related disorders: a report of the International Myeloma Working Group. Brit J Haematol 2003; 121: 749-757.

17. Scudla V, Bacovsky J, Vytrasova M, Ordeltova M, Papajik T, Opichalova D, et al. Prognostic factors and clinical staging systems in multiple myeloma in the group of 237 patients from the years 1991-2002 treated with conventional chemotherapy. I. Prognostic significance of selected clinical and laboratory markers. Klin Onkologie 2002; 15(Suppl 2): 7-14.

18. Scudla V, Bacovsky J, Vytrasova M, Ordeltova M, Budikova M, Papajik T, et al. Prognostic factors and clinical staging systems in multiple myeloma in the group of 237 patients from the years 1991-2002 treated with conventional chemotherapy. II. Prognostic significance of some existing staging systems. Klin Onkologie 2002; 15(Suppl 2): 15-20.

19. Kyrtsonis MC, Dedoussis G, Zervas C, Perifanis V, Baxevanis C, Stamatelou M, et al. Soluble interleukin-6 receptor (sIL-6R), a new prognostic factor in multiple myeloma. Brit J Haematol 1966; 93: 398-400.

20. Papadaki H, Kyriakon DS, Fondoulakis A, Markidon F, Alexandrakis MG, Eliopoulos GD. Serum levels of soluble interleukin-6 receptor in multiple myeloma as on indicator of disease activity. Acta Haematol 1997; 97: 191-195.

21. Cook G, Dunbar M, Franklin IM. The role of adhesion molecules in multiple myeloma. Acta Haematol 1997; 97: 81-89.

22. Ščudla V, Budíková M, Bačovský J, Opichalová D, Farbiaková V. Vztah hladin solubilních cytoadhezivních molekul VCAM1 a ICAM-1 k vybraným klinickým a laboratorním ukazatelům mnohočetného myelomu. Čas Lék čes 2000; 139: 401-406.

23. Abildgaard N, Bentzen SM, Nielsen JL, Heickendorff L, for the Nordic Myeloma Study Group (NMSG). Serum markers of bone metabolism in multiple myeloma: Prognostic value of the carboxyterminal telopeptide of type I collagen (ICTP). Brit J Haematol 1997; 96: 103-110.

24. Risteli L, Risteli J. Biochemical markers of bone metabolism. Ann Medicine 1993; 25: 385-393.

25. Fonseca R, Trendle MC, Leong T, Kyle RA, Oken MM, Kay NE. Prognostic value of serum markers of bone metabolism in untreated multiple myeloma patients. Brit J Haematol 2000; 109: 24-29.

26. Heider U, Fleisner C, Zavrski I, Kaiser M, Hecht M, Jakob Ch, et al. Bone markers in multiple myeloma. Eur J Cancer 2006; 42: 1544-1553.

27. Terpos E. Biochemical markers of bone metabolism in multiple myeloma. Cancer Treat Rev 2006; 32(Suppl 1): 15-19.

28. Standal T, Seidel C, Hjertner Q, Plesner T, Sanderson D, Waage A, et al. Osteoprotegerin is bound, internalized, and degraded by multiple myeloma cells. Blood 2002; 100: 3002-3007.

29. Goranova-Marinova V, Goranov S, Pavlov P, Tzvekova T. Serum levels of OPG, RANKL and RANKL/OPG ratios in newly - diagnosed patients with multiple myeloma (clinical correlation). Haematologica 2007; 92: 1000.

30. Corso A, Dovio A, Rusconi C, Sartori ML, Klersy C, Varetkoni M. Osteoprotegerin serum levels in multiple myeloma and MGUS patients compared with age and sex-matched healthy controls. Leukemia 2004; 18: 1555-1557.

31. Terpos E, Szydlo R, Apperley JF, Hatjiharissi E, Politou M, Meletris J, et al. Soluble receptor activator of nuclear factor $\kappa-B$ ligand - osteoprotegerin ratio predicts survival in multiple myeloma: proposal for a novel prognostic index. Blood 2003; 102: 1064-1069.

32. Du W, Hattori Y, Yamada T, Matsumoto K, Nakamura T, Sagawa $\mathrm{M}$, et al. $\mathrm{NK}_{4}$, an antagonist of hepatocyte growth factor (HGF), inhibits growth of multiple myeloma cells: molecular targeting of angiogenic growth factor. Blood 2007; 109: 3042-3049.

33. Sugimura K, Lee CR, Kim T, Goho T, Kasai S, Harimoto K, et al. Production of hepatocyte growth factor is increased in chronic renal failure. Nephron 1996; 75: 7-12.

34. Di Raimondo F, Azzaro MP, Palumbo GA, Bagnato S, Giustolisi G, Floridia PM, et al. Angiogenic factors in multiple myeloma: higher levels in bone marrow than in peripheral blood. Haematologica 2000; 85: 800-805.

35. Alexandrakis MG, Passam FH, Boula A, Christophoridon A, Aloizos G, et al. Relationship between circulating serum soluble interleukin-6 receptor and the angiogenic cytokines basic fibroblast growth factor and vascular endothelial growth factor in multiple myeloma. Ann Hematol 2003; 82: 19-23.

36. Sezer O, Jakob C, Eucker J, Niemoller K, Gatz F, Wernecke KD, et al. Serum levels of the angiogenic cytokines basic fibroblast growth factor (bFGF), vascular endothelial growth factor (VEGF) and hepatocyte growth factor (HGF) in multiple myeloma. Eur J Haematol 2001; 66: 83-88.

37. Dhodapkar MV, Sanderson RD. Syndecan-1 $\left(\mathrm{CD}_{138}\right)$ in myeloma and lymphoid malignancies: a multifunctional regulator of cell behavior within the tumor microenvironment. Leuk Lymphoma 1999; 34: $35-43$.

38. Dhodapkar MV, Kelly T, Theus A, Athota AB, Barlogie B, Sanderson RD. Elevated levels of shed syndecan-1 correlated with tumour mass and decreased matrix metalloproteinase- 9 activity in the serum of patients with multiple myeloma. Br J Haematol 1997; 99: $368-371$.

39. Kyrtsonis MC, Vassilakopoulos TP, Siakantaris MP, Kokoris SI, Gribabis DA, Dimopoulos NM, et al. Serum syndecan-1, basic fibroblast growth factor and osteoprotegerin in multiple myeloma patients at diagnosis and during the course of the disease. Eur J Haematol 2004; 72: 252-258.

40. Janosi J, Sebestydu A, Mikala G, Nemeth J, Kiss Z, Valyi-Nagy I. Soluble syndecan-1 levels in different plasma cell dyscrasias and in different stages of multiple myeloma. Haematologica 2004; 89: 370-371.

41. Frassanito MA, Silvestris F, Silvestris N, et al. Fas/Fas ligand (FasL)-deregulated apoptosis and IL-6 insensibility in highly malignant myeloma cells. Clin Exp Immunol 1998; 114: 711-720.

42. Schaar CG, Vermeer HJ, Wijermans PW, Huisman W, Cessie S, Kluin-Nelemans HC. Serum syndecan-1 in patients with newly 
diagnosed monoclonal proteinaemia. Haematologica 2005;90: $1437-1438$.

43. Maisnar V, Touskova M, Maly J, Krejsek J, Kmonicek M, Kopecky $\mathrm{O}$, et al. Importance of selected laboratory indicators in the differential diagnosis and monitoring of multiple myeloma. Vnitr Lek 2002; 48: 290-297.
44. Frassanito MA, Silvestris F, Silvestris N, et al. Fas/Fas ligand (FasL)-deregulated apoptosis and IL-6 insensibility in highly malignant myeloma cells. Clin Exp Immunol 1998; 114: 711-720.

45. Niitsu N, Sasaki K, Umeda M. A high serum soluble Fas/Apo-1 level is associated with a poor outcome of aggressive non-Hodgkin's lymphoma. Leukemia 1999; 13: 1434-1440. 